\title{
Anatomical Changes in Rudbeckia hirta L. during Transition to Flowering
}

\author{
Richard L. Harkess ${ }^{1}$ and Robert E. Lyons ${ }^{2}$ \\ Department of Horticulture, Virginia Polytechnic Institute and State University, Blacksburg, VA24041 -0327
}

Additional index words. Asteraceae, black-eyed Susan, floral anatomy, floral development, floral initiation, photoperiod

\begin{abstract}
Histological and histochemical examination of floral initiation was conducted to determine the pattern of flowering in Rudbeckia hirta, a long-day (LD) plant. Plants were grown under 8-hour short days (SDs) until they had 14 to 16 expanded leaves. Half of the group of plants was moved to LD conditions consisting of natural daylength plus a 4 hour night interruption. Rudbeckia hirta had a pattern of differentiation in flowering similar to that reported in species requiring one inductive day for initiation. Rudbeckia hirta required 8 LDs for evocation and 18 LDs for completion of initiation. Involucral bracts initiated after $18 \mathrm{LDs}$, after which the receptacle enlarged and was capped by a meristematic mantle of cells signaling the start of development. Floret primordia did not initiate, even after 20 LDs. Increases in pyronin staining were observed in actively dividing cells of the procambium, leaf primordium, and corpus of the vegetative meristems. After $8 \mathrm{LDs}$, the pith rib meristem stained darkly, a result indicating the arrival of the floral stimulus. An increase in pyronin staining was also observed in the meristematic mantle covering the receptacle after 18 LDs, a result indicating increased RNA levels.
\end{abstract}

All flowering plants share the same stages of floral morphogenesis, although species, and even individuals within a species, can be heterogeneous in their response to floral inductive conditions (Bernier, 1989). Meristems are composed of distinct zones that change during floral initiation and ultimately become unrecognizable (Bernier et al., 1981; Esau, 1977). The typical vegetative meristem is comprised of the tunica, a two- or three-cell layer of anticlinally dividing cells capping the meristem (Esau, 1977), and the corpus, which is comprised of three zones. The central zone of the corpus consists of large, slowly dividing cells (Bernier et al., 1981; Jacqmard, 1970). The peripheral zone is approximately ring shaped and surrounds the central zone with smaller, actively dividing cells from which all leaf primordia and stem tissue, except the central pith, originate. The pith rib meristem, a zone of large, flattened, vacuolated cells, lies immediately below the central zone; periclinal divisions in this region and parts of the peripheral zone give rise to stem elongation in caulescent species. This zone disappears with floral development (Bernier et al., 1981; Nougarède, 1967). According to Bernier et al. (1981), the most significant finding of the histological and histochemical study of meristems is that a prefloral stage, characterized by peak activation and division of cells in the central and peripheral zones, is identifiable during floral transition in almost all species, regardless of inductive requirements.

In the Asteraceae, after transition to inductive conditions, cell activity increases in the central zone and cells stain darkly with pyronin, an RNA-specific stain (Bernier et al., 1981; Jacqmard et al., 1972; Nougarede, 1967). This stage is followed by an increase in cell division and a subsequent loss of distinct zonation, and the meristem begins to dome as a result of periclinal divisions and elongation in the pith rib meristem. Involucral bracts develop first and, although leaf-like, they can be distinguished from true leaves as they arise from periclinal divisions in the second tunica layer without prior formation of a foliar buttress (Bernier et al., 1981; Philipson, 1946). The parenchymatous core continues to enlarge,

Received for publication 9 Nov. 1992. Accepted for publication 26 Mar. 1993. The cost of publishing this paper was defrayed in part by the payment of page charges. Under postal regulations, this paper therefore must be hereby marked advertisement solely to indicate this fact.

${ }^{1}$ Graduate assistant.

${ }^{2}$ Associate professor. giving rise to the receptacle. Several layers of meristematic cells expand over the entire receptacle surface, creating a mantle that stains darkly for nucleic acids. Periclinal divisions in the lower layers of the mantle give rise to floret primordia. These form acropetally, rapidly covering the entire surface of the receptacle (Bernier et al., 1981; Nougarède, 1967).

In Rudbeckia hirta (syn. R. bicolor), 4 long days (LDs) were reported to be sufficient for floral evocation (Milyaeva and Chailakhyan, 1981). Significant meristematic changes did not occur until after this evocation period. Stem elongation and subsequent floral initiation followed a pattern of activation also observed in Sinapis alba L. (Bernier et al., 1974; Milyaeva and Chailakhyan, 1981).

We used histological and histochemical techniques to determine the pattern of anatomical change in R. hirta during the transition to flowering.

\section{Materials and Methods}

Rudbeckia hirta were sown in Sunshine Mix 1 (Fisons Horticulture, Vancouver, B.C., Canada) on 18 Dec. 1989 and kept under short-day (SD) conditions by covering the plants with black cotton cloth from 1700 to $0800 \mathrm{HR}$. After 1 month, seedlings were transplanted into the same medium in 500-ml (10-cm-diameter) containers and grown to 14 to 16 expanded leaves under SDs, i.e., maturity as defined by Orvos and Lyons (1989). On 21 Mar. 1990, 105 plants were moved to inductive LDs, while 105 remained as controls under SDs. LD treatments consisted of ambient greenhouse light [623 to $833 \mathrm{~mol} \cdot \mathrm{s}^{-1} \cdot \mathrm{m}^{-2}$ photosynthetic photon flux (PPF)] plus a 4-h night interruption from 2200 to $0200 \mathrm{HR}$ using overhead $60-\mathrm{W}$ incandescent bulbs emitting 3 to $4 \mathrm{~mol} \cdot \mathrm{s}^{-1} \cdot \mathrm{m}^{-2}$ PPF. A completely random design was used. Ten plants were sampled daily between 0800 and $0900 \mathrm{HR}$ for 21 days (0 to $20 \mathrm{LDs}$ ), five from LD and five from SD conditions to serve as paired comparisons of induced and noninduced plants of equivalent chronological age. The collected meristems were fixed at $6 \mathrm{C}$ in $2.5 \%$ glutaraldehyde and $2 \%$ paraformaldehyde (v/v) in $0.1 \mathrm{M}$ sodium cacodylate buffer for $24 \mathrm{~h}$, then transferred to buffer for storage at $6 \mathrm{C}$ until all meristems were collected.

The meristems were dehydrated in an ethanol series $(25 \%$, $40 \%, 50 \%, 70 \%, 80 \%, 95 \%, 100 \%$, and $100 \%$ ), embedded in paraffin, and sectioned serially at $8 \mu \mathrm{m}$ (Berlyn and Miksche, 
1976). Tissue sections were mounted and stained using chloroform-washed methyl-green-pyronin, which stains RNA red and DNA green (Kurnick, 1952, 1955; Pearse, 1985). A comparative control group of serial sections was stained after clearing with ribonuclease (RNase) to discriminate non-RNA cellular material also stained by the pyronin (Kurnick, 1955). The staining sequence was as follows: 1) immerse in xylene, $5 \mathrm{~min}$; 2) rehydrate in ethanol-100\%, 95\%, 70\%, and 50\%, $3 \mathrm{~min}$ each; 3) rinse in distilled water, $3 \mathrm{~min}$; 4) rinse in distilled water at $37 \mathrm{C}$ for $2 \mathrm{~h}$; 5) rinse in distilled water twice, 2 min each; 6) stain with methylgreen pyronin, $6 \mathrm{~min}$; 7) blot excess stain; 8) immerse in two changes of $n$ - butyl alcohol, $5 \mathrm{~mm}$ each; 9) immerse in xylene, 5 min; 10) immerse in cedar oil, 5 min; 11) mount. (Kurnick, 1955)
The comparative control slides were immersed in RNase $(0.25$ $\mathrm{mg} \cdot \mathrm{ml}^{-1}$ ) at $37 \mathrm{C}$ for $2 \mathrm{~h}$ at Step 4 and staining continued as above. Before use, the RNase solution was warmed to $90 \mathrm{C}$ for $10 \mathrm{~min}$ to deactivate any deoxyribonuclease (DNase) contaminants (Kurnick, 1952, 1955).

We then examined the disorganization and dissociation of the tunica and corpus layers and associated anatomical changes during transition to flowering using light microscopy.

\section{Results}

Anatomical changes in the $R$. hirta meristem during flowering were observed (Fig. 1 A-H, Fig. 2 A-C). Rudbeckia hirta vegeta-

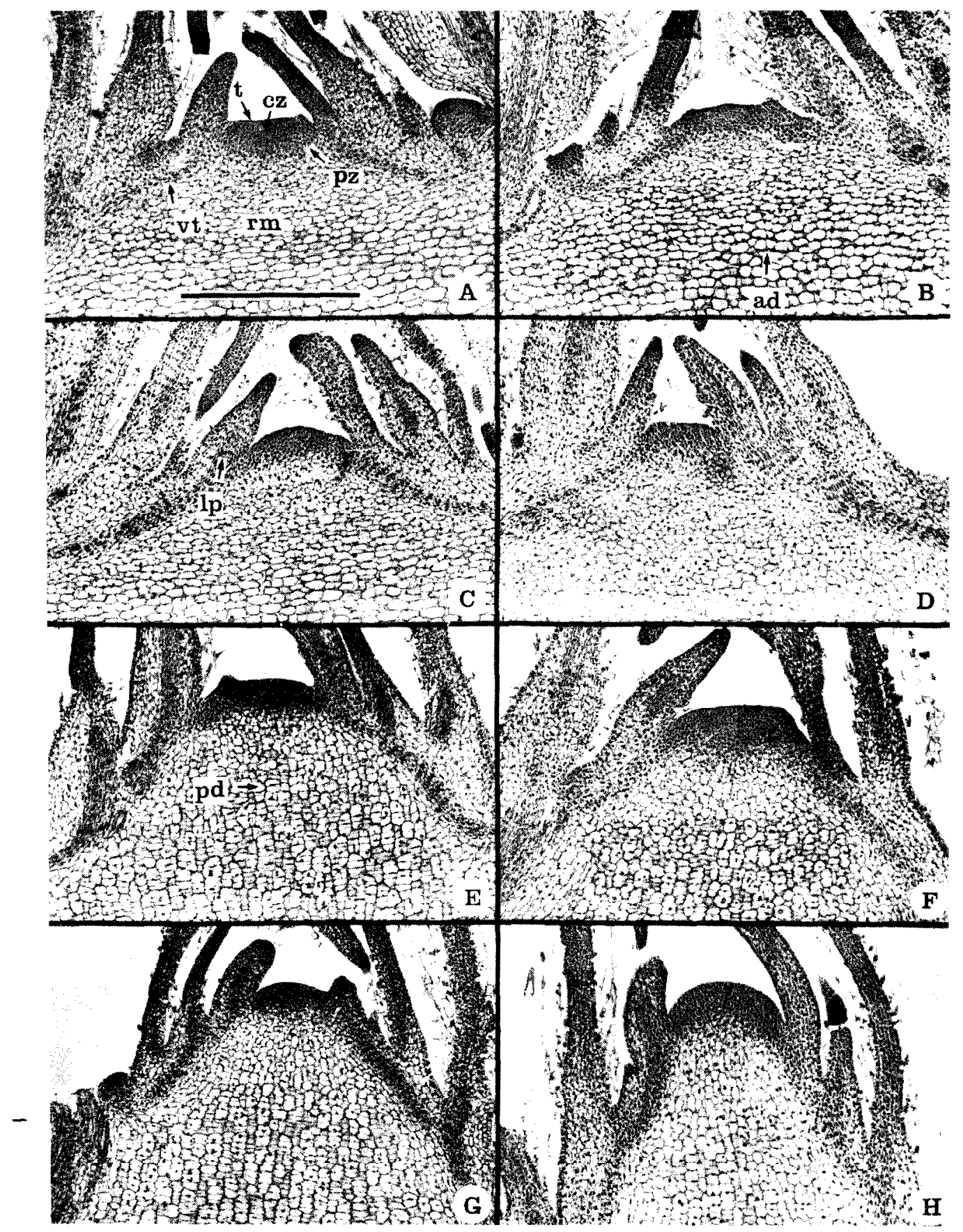

Fig. 1. Longitudinal sections of Rudbeckia hirta meristems, after exposure to (A) $0,(\mathbf{B}) 2$, (C) $4,(\mathbf{D}) 6,(\mathbf{E}) 8$, (F) 10, (G) 12 , or (H) 14 long days, illustrating the anatomical changes during photoperiodic induction of flowering. $\mathrm{t}=$ Tunica layer, $\mathrm{pz}=$ peripheral zone, $\mathrm{cz}=$ central zone, $\mathrm{rm}=$ pith rib meristem, $\mathrm{vt}=\mathrm{vascular}$ trace-procambium, $\mathrm{l} p=$ leaf primordium, $\mathrm{pd}=$ periclinal division, $\mathrm{ad}=$ anticlinal division. $\mathrm{Bar}=1.0 \mathrm{~mm}$. 
tive meristems had a tunica layer, about two cells thick, and distinct zonation in the corpus consisting of the central zone, peripheral zone, and pith rib meristem (Fig. 1A). Plants held under SDs as

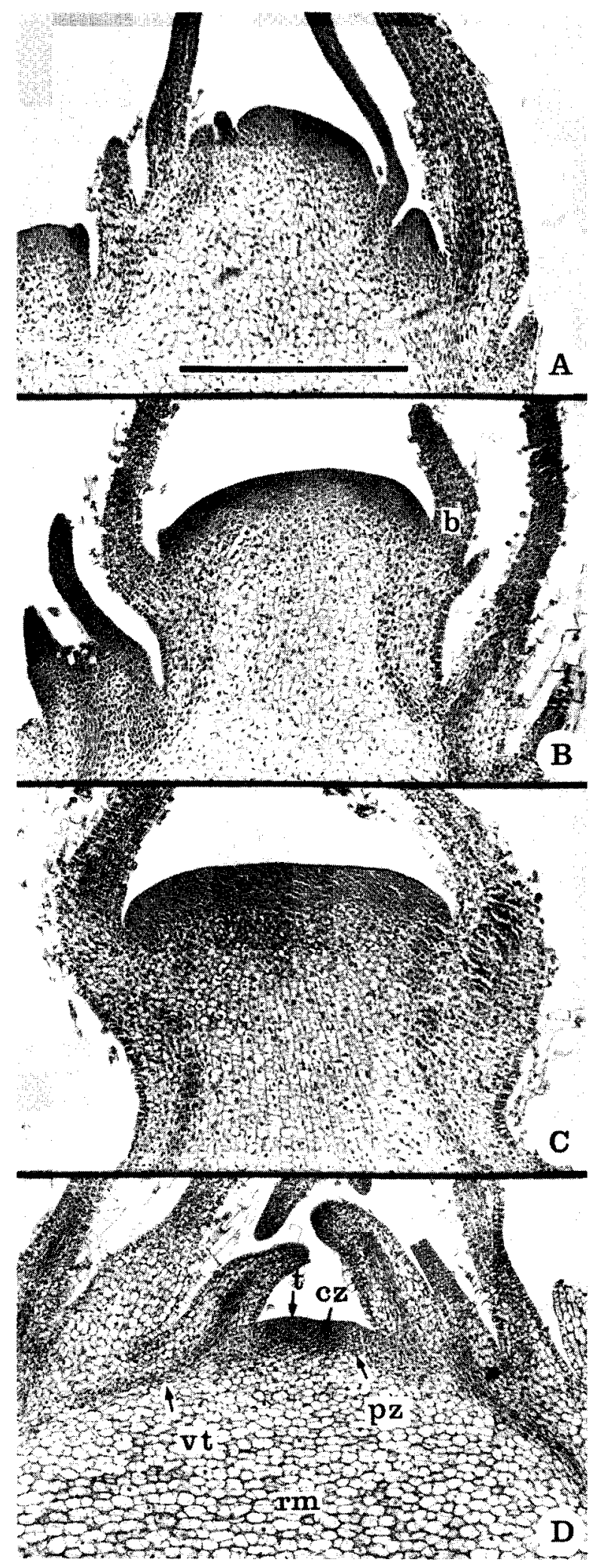

Fig. 2. Longitudinal sections of Rudbeckia hirta after exposure to (A) 16, (B) 18 , or (C) 20 long days, or (D) 20 short days. $b=B$ ract, $t=$ tunica layer, $p z=$ peripheral zone, $\mathrm{cz}=$ central zone, $\mathrm{rm}=$ pith rib meristem, $\mathrm{vt}=$ vascular trace-procambium . $\mathrm{Bar}=1.0 \mathrm{~mm}$. paired controls remained vegetative through to the end of the experiment (Fig. 2D). The vascular traces, or procambium, were observed in a nearly horizontal orientation extending out from the foliar buttresses and leaf primordia in the meristem. The small, dense, actively dividing cells of the procambium, leaf primordia, and corpus stained darkly with pyronin (Fig. 3A); but, when cleared with RNase, these areas stained only lightly, if at all (Fig. 3B). No difference between RNase-cleared and uncleared sections was found in the large vacuolated, slowly dividing cells of the pith rib meristem. The nuclei of the dense cells in the leaf primordia, procambium, and corpus had an affinity for the DNA-favoring methyl-green stain, especially during reproductive differentiation under LDs. All SD paired controls remained similar, in anatomy and pyronin staining, to the 0 LD plants, even after 20 LDs (not shown).

Corpus zonation disintegrated rapidly in plants subjected to inductive LDs and completely disappeared after 4 to 6 LDs (Fig. $1 \mathrm{C}$ and D). Meristem doming began after 4 LDs (Fig. 1C) and the procambium reoriented from nearly horizontal to nearly vertical. After 8 LDs, a qualitative increase in pyronin staining, which cleared with RNase (Fig. 3D), was observed in the pith rib meristem and central zone (Fig. 3C). At this time, periclinal divisions in the pith rib meristem were observed (Fig. 1E). No increase in pyronin staining was observed after 14 LDs (Fig. $3 \mathrm{E}$ and $\mathrm{F}$ ). Periclinal divisions continued during inflorescence initiation (Fig. 1 F-H, Fig. 2 A-C), with observable cell elongation beginning after $14 \mathrm{LDs}$ (Fig. $1 \mathrm{H}$ ). As the stem elongated, the procambium became more vertical until after 18 LDs, when initiation of the involucral bracts commenced (Fig. 2B). Once bract formation began, the mantle was subtended by a shallow region of randomly dividing cells (Fig. 2B). Enlargement of the meristem was accompanied by an increased affinity for pyronin staining in the areas of active cell division (Fig. $3 \mathrm{G}$ and $\mathrm{H}$ ). The cells in the corpus region, below the mantle, continued to divide randomly, increasing the receptacle size, and, by $18 \mathrm{LDs}$, the dome was capped by a uniform, multi-layered mantle of cells (Fig. 2B). Below the receptacle, cells continued to divide periclinally, with considerable stem elongation initially beginning after 12 LDs (Fig. $1 \mathrm{G})$. Floret primordia had not initiated by $20 \mathrm{~s} \mathrm{LD}$, the end of the study (Fig. 2C).

\section{Discussion}

At the molecular level, differentiation during all stages of floral morphogenesis is the result of activation and repression of gene expression (Esau, 1977). The appropriate external stimulus regulates gene activity, thus evoking the synthesis of specific enzymes that determine the path toward floral differentiation (Esau, 1977), even before morphological changes are evident. In $R$. hirta, LD-induced anatomical changes preceded foliage arching, a visible morphological change that first appeared after 8 to $10 \mathrm{LDs}$ (Murneek, 1940). The observed increase in pyronin staining after only 8 LDs indicated molecular level changes in response to a stimulus. After $8 \mathrm{LDs}$, directional changes in cell division were also observed. Increases in RNA after exposure to floral inductive conditions have also been reported in Chrysanthemum segatum L. and Sinapis alba (Bernier et al., 1981; Jacqmard et al., 1972), a change signaling evocation of flowering.

Applying nucleic acid inhibitors to the meristem during evocation inhibits flowering, a result showing that this early increase in RNA synthesis is essential to flowering (Bernier, 1971). Findings by Bernier (1971) in Pharbitis nil Chois., S. alba, and Lolium temulentum L. show an increase in RNA eitherjust before or on the 

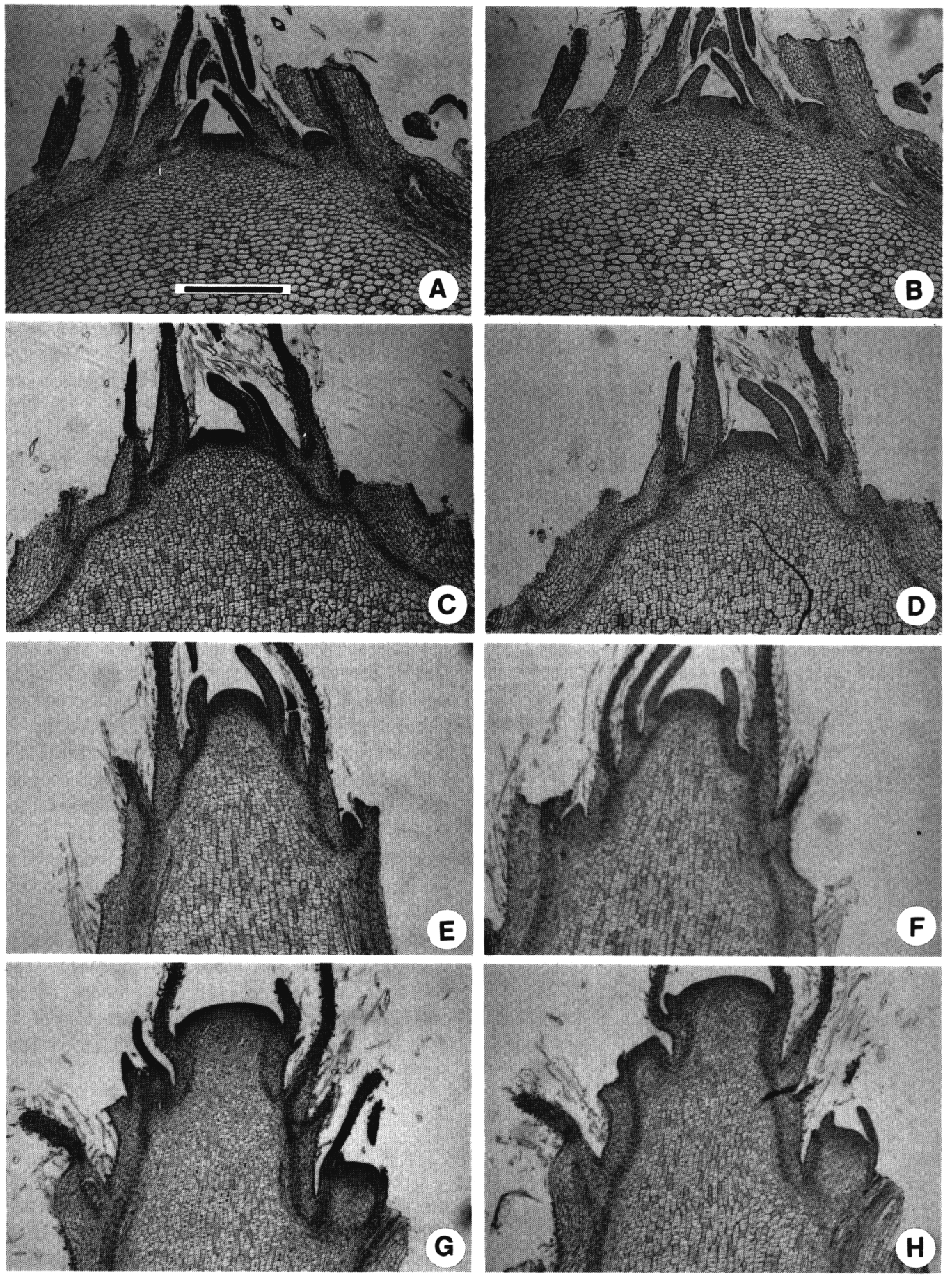

Fig. 3. Longitudinal soctions of Rudbeckia hirta during floral initiation after staining with (D) 8 , Rnase chaned

(E) 14; (F) 14, Rhase clarred,

(G) 18; and

with mathyl-groesn-pyronin. Exposure was to

(A) 0; (B) 0, QRnase cleared;

(C) 8

arrival of the floral stimulus. In the present study, the RNA increase in $R$. hirta after 8 LDs suggests that the floral stimulus arrives at the meristem a few days later than previously described in this species (Milyaeva and Chailakhyan, 1981). The difference most likely is attributable to the limitation of their study to only the first 4 LDs. Another difference was the prevailing temperatures and incident light quantity during experimentation. Flowering in $R$. hirta has been observed to be greatly affected by these two factors (Mumeek, 1940). Milyaeva and Chailakhyan (1981) used 18-h natural LDs in Moscow, while we used natural daylength plus a 4-h night interruption. The low light of winter months in Virginia may have caused the delayed response.
Once cells begin their increased activity, flowering moves into the initiation stage. At this time, distinct zonation in the meristem is lost (Bernier et al., 1981; Nougarede, 1967). This phenomenon was observed in $R$. hirta after 6 LDs. Increased cell division in the corpus, combined with periclinal division in the pith rib meristem, is described by Bernier et al. (1981) as the prefloral stage. This stage has been described in several species from diverse plant families, ranging from primitive to advanced (Bernier et al., 1981). A similar prefloral stage occurring between 8 and 14 LDs was identifiable in $R$. hirta. During this stage, Murneek (1940) reported, and we observed, that the foliage of $R$. hirta assumed a more vertical orientation when daylengths reached $12 \mathrm{~h}$; Murneek 
referred to this as the first visible sign of change in development toward flowering. Rapid elongation of the stem (bolting) did not follow immediately, rather was delayed by almost 2 weeks in plants grown under days slightly longer than $12 \mathrm{~h}$ (Murneek, 1940). The vertical orientation of the leaves may be linked to the proliferation of periclinal divisions, with minimal cellular elongation occurring during the prefloral stage. We observed such arching after 8 to 10 LDs.

In the Asteraceae, the prefloral stage ends abruptly with the initiation of involucral bracts, an action signaling the transition to floral development stage (Nougarède, 1967). This stage is characterized by floral determination, whereby a plant will continue to develop to anthesis, even if removed from inductive conditions (Bernier et al., 1981). Involucral bracts are the first structures that are directly associated with the inflorescence to appear. In Petasites hybridus L., removing or injuring the developing bracts results in a reversion to the vegetative state (Wardlaw, 1963). In $R$. hirta, these bracts initiated after 18 LDs. This stage is also characterized by rapid stem elongation resulting from cell elongation in the region below the corpus (Bernier et al., 1981). Murneek (1940) noted that rapid elongation occurred $\approx 2$ weeks after leaf arching in $R$. hirta. In the present study, the start of rapid cellular elongation in the pith rib meristem occurred between 12 and 14 LDs. Rapid elongation of the stem is not required for $R$. hirta flowering, but it is a response to the same photoperiod treatment that stimulates flowering (Murneek, 1940).

After $16 \mathrm{LDs}$, the meristem began increasing in size to form a large parenchymous core that eventually developed into the receptacle core with large vacuolated cells. Periclinal divisions and cell elongation continued below this region to increase stem length. As in Bellis perennis L. (Philipson, 1946), the meristem in R. hirta formed a high dome with meristematic sides along which arose the involucral bracts subtending the inflorescence.

As the receptacle enlarged, the meristematic mantle stained darkly for RNA. This staining likely resulted from increased cellular activity during bract initiation and preceded floret primordia initiation, as reported in other Asteraceous species (Nougarède, 1967). Philipson (1946) reported that floret primordia in Bellis arose from the bottom layer of cells in the mantle. In $R$. hirta, it was not possible to determine primordia origin, as they did not initiate before the end of the experiment, after 20 LDs.

While the pattern of flowering in R. hirta has been shown to be similar to that of other species, many species require far less time for completion of flowering. As demonstrated by Murneek (1940) photoperiod triggers flowering in $R$. hirta, but postinitiation temperature and light conditions regulate the speed at which floral development occurs, a result emphasizing the need to understand species-specific responses. Our study described the pattern of anatomical changes during floral initiation in $R$. hirta. It advances the work of Milyaeva and Chailakhyan (1981) by extending the understanding of the transition to flowering in this species beyond the first 4 LDs. Given the pattern and sequence of flowering events, floral manipulation treatments can be planned and interpreted more accurately.

\section{Literature Cited}

Berlyn, G.P. and J.P. Miksche. 1976. Botanical microtechnique and cytochemistry. Iowa State Univ. Press, Ames.

Bernier, G. 1971. Structural and metabolic changes in the shoot apex in transition to flowering. Can. J. Bot. 49:803-819.

Bernier, G. 1989. Events of the floral transition of meristems, p. 42-50. In: E. Lord and G. Bernier (eds.). Plant reproduction: From floral induction to pollination. vol. 1. Amer. Soc. Plant Physiol. Symp. Ser.

Bernier, G., J.M. Kinet, M. Bodson, Y. Rouma, and A. Jacqmard. 1974. Experimental studies on the mitotic activity of the shoot apical meristem and its relation to floral evocation and morphogenesis in Sinapis alba. Bot. Gaz. 135:345-352.

Bernier, G., J.M. Kinet, and R.M. Sachs. 1981. The physiology of flowering. vol. 2. CRC Press, Boca Raton, Fla.

Esau, K. 1977. Anatomy of seed plants. 2nd ed. Wiley, New York.

Jacqmard, A. 1970. Duration of the mitotic cycle in the apical bud of Rudbeckia bicolor. New Phytol. 69:269-271.

Jacqmard, A., J.P. Miksche, and G. Bernier. 1972. Quantitative study of nucleic acids and proteins in the shoot apex of Sinapis alba during transition from the vegetative to the reproductive condition. Amer. J. Bot. 59:714-721.

Kurnick, N.B. 1952. Histological staining with methyl-green-pyronin. Stain Technol. 27:233-242.

Kurnick, N.B. 1955. Pyronin Y in the methyl-green-pyronin histological stain. Stain Technol. 30:213:230.

Milyaeva, É.L. and M.K. Chailakhyan. 1981. Daily fluctuations of mitotic activity in stem apices of Rudbeckia bicolor during the period of floral evocation. Soviet Plant Physiol. 28:212-216.

Murneek, A.E. 1940. Length of day and temperature effects in Rudbeckia. Bot. Gaz. 102:269-279.

Nougarède, A. 1967. Experimental cytology of the shoot apical cells during vegetative growth and flowering, p. 203-351. In: G.H. Bourne and J.F. Danielli (eds.). International review of cytology. vol. 21. Academic Press, New York.

Orvos, A.R. and R.E. Lyons. 1989. Photoperiodic inhibition of stem elongation and flowering in Rudbeckia hirta 'Marmalade'. J. Amer. Soc. Hort. Sci. 114:219-222.

Pearse, A.G.E. 1985. Histochemistry: Theoretical and applied. vol. 2.4th ed. Churchill Livingstone, New York.

Philipson, W.R. 1946. Studies in the development of the inflorescence I. The capitulum of Bellis perennis L. Ann. Bot. 10:257-270.

Wardlaw, C.W. 1963. Experimental investigations of floral morphogenesis in Petasites hybridus. Nature 198:560-561. 